Research article

\title{
Comparative study of the floristic and structural diversity of three lowland forests of the former Province Orientale, Democratic Republic of the Congo
}

\author{
Jean-Léon K. Kambale ${ }^{1}$, Bernard T. Malombo', Eric W. Katembo², Reddy E. Shutsha ${ }^{1}$, \\ Judith M. Tsongo ${ }^{1}$, Elie P. Bugentho ${ }^{1}$, Patrick K. Mutombo ${ }^{1}$, Roger A. Angoyo ${ }^{1}$, \\ Hyppolyte S. Nshimba ${ }^{2}$, Gédéon N. Bongo ${ }^{1 *}$ and Koto-te-Nyiwa Ngbolua ${ }^{3}$
}

${ }^{1}$ Centre de Surveillance de la Biodiversité, Université de Kisangani, B.P. 2012 Kisangani, RD Congo ${ }^{2}$ Faculty of Sciences, University of Kisangani, P.O. Box. 2012 Kisangani, Democratic Republic of the Congo ${ }^{3}$ Department of Biology, Faculty of Sciences, University of Kinshasa, P.O. Box. 190, Kinshasa XI, Democratic Republic of the Congo

*Corresponding Author: gedeonbongo@gmail.com

[Accepted: 23 March 2019]

\begin{abstract}
The present study was carried out in the aim of comparing the floristic diversity, the areal richness and the structure of three lowland forest types of the former Province Orientale notably Rubi Télé in Buta territory, UMA in Ubundu territory and Wela in Aketi territory. This comparative study is a contribution to the improvement of knowledge on the influence of soil type and the remoteness of forest types on the floristic composition and distribution of species in the lowland forests of the former Province Orientale. To achieve this, an inventory of all trees with $\mathrm{dbh} \geq 10 \mathrm{~cm}$ (all species combined) in 36 plots of 0.25 ha was performed. At the end of this floristic and structural study conducted in the forests, we counted a total of 1120 individuals distributed to 191 species in 40 families in these three different sites. The average basal area for these three sites is $25.40 \mathrm{~m}^{2} \mathrm{ha}^{-1}$. In terms of group diversity, the ANOVA test showed no significant differences, because $F=1.844, \mathrm{p}$ value is greater than 0.05 , either 0.213 . In terms of diametric structure, the chi-square was calculated Chi-square $=35.5599, \mathrm{df}=18, \mathrm{p}$ value $=$ 0.00803. The density for extrapolation (per hectare) with ANOVA the value for $F=7.91, p$ value $=0.0104$ this shows that there was a significant difference.
\end{abstract}

Keywords: Diversity - Lowland forest - Province Orientale - DRC.

[Cite as: Kambale J-JK, Malombo BT, Katembo EW, Shutsha RE, Tsongo JM, Bugentho EP, Mutombo PK, Angoyo RA, Nshimba HS, Bongo GN \& Ngbolua K-t-N (2019) Comparative study of the floristic and structural diversity of three lowland forests of the former Province Orientale, Democratic Republic of the Congo. Tropical Plant Research 6(1): 63-73]

\section{INTRODUCTION}

In the current situation in which human society seeks to develop from environmental resources, the major challenge is to know the place as well as the importance of terrestrial biodiversity in this environment. The environment is threatened following the search for the livelihoods of living beings, particularly man. Threats to biodiversity, including deforestation, environmental degradation and crop unification, have re-actualized the issue of the origin and maintenance of biodiversity (Carpentier 1999).

In recent decades, deforestation and degradation of tropical rainforest have attracted considerable international attention. Therefore, the Rio Conference in 1992 called for the sustainable management of these forests as the most effective means of combating their accelerated degradation (CBD 2012). These tropical forests host many species and are among the richest ecosystems on our planet (Omatoko et al. 2015, Asimonyio et al. 2015a,b). The multiple interactions of species with each other and with their environment make these forests extremely complex ecosystems (Kambale et al. 2016a). At the phytoecological level, the population of a region can be considered from two different points of view; either its floristic groupings (dynamism) or their 
structure (physiognomy) (Kambale et al. 2016b, Bajpai et al. 2017). Plant formations are sensitive to local environmental conditions such as soil, topography, sunshine, humidity and it is generally observed that the composition and structure of an ecosystem vary from a location to another depending on the local values of these factors (Kambale et al. 2016c). Despite this complexity, the ecological richness of tropical rainforests stimulates several topics of research in order to better understand its origins and the mechanisms of its maintenance in order to have a better conservation (Blanc et al. 2003). The complexity of the forest structure observed at the scale of a station (floristic and three-dimensional structure) comes from a large number of plant species, their varied architecture and of the coexistence of different phases of development at a specific moment (Trichon 1997). This complexity is also explained by the lack of a non-mastery of all the keys of identification of the species on the field and this identification remains a puzzle in botany. The immense richness of tropical rainforests equals the complexity of their ecological mechanisms.

Tropical forests are exceptional reservoirs of biodiversity, as many researchers in the world have experienced. For several decades, they have been at the heart of international issues on climate change (Marquant et al. 2015). The protection of biodiversity has become a major issue in forest policy but before getting there, it is imperative to know the composition of these ecosystems which deserves particular emphasis today for their valorization (Timilsina et al. 2007, Sambare et al. 2011, Bajpai et al. 2015, Masens et al. 2017). A very crucial step in the negotiation of carbon credit for the countries which still conserve their forests as a carbon sink.

The Democratic Republic of Congo (DRC) is a region that hosts enormous biodiversity and its forests are classified among the richest ecosystems on the planet. However, its forest is among the least studied ecosystems in Africa. With climate change, there is a risk of seeing the disappearance of several species that are bad or not yet known. Also, DRC has a great wealth of watercourses by its river that runs from South to North and from East to West, and its affluents including Itimbiri, Tshopo, Lindi, Aruwimi, Kwango and Kwilu rivers. In a botanical point of view, there are few studies conducted along these rivers in the country (CSB 2014). From this, it is necessary to provide other researchers with information on the structure and floristic diversity of three forest types, including one along the large river in the province of Bas Uélé called ITIMBIRI. In addition, research in the Province Orientale in general and that of the Tshopo, in particular, are numerous, nevertheless, it would also be better to compare them with the forests of other parts of the Province Orientale still little known. Therefore, we tried to compare three forest types including UMA in the territory of Ubundu in Tshopo province, Rubi-Télé in the territory of Buta and Wela in Aketi territory, both in Bas-Uele province. It is in this context that a multidisciplinary team undertook a survey in Aketi, UMA and Wela in order to contribute to the better knowledge of the biodiversity of the former Province Orientale so that its biological resources might be known at the scientific level and this would help the policy-makers in decision-making. In order to spread its biological (forest) resources on a scientific level and this will help the decision-makers in decision-making. Due to the remoteness, soil types and ecological barriers including rivers between the three sites which are totally different in all aspects of the florule constitute the main topic of this study.

\section{MATERIAL AND METHOD}

Study area

This research was carried out in three sites of the former Province Orientale. The first site is located in Aketi territory in the village of Wela, Bas Uele province which has the following geographical coordinates: latitude $024^{\circ} 01^{\prime} 35.1^{\prime \prime}$ \& longitude $03^{\circ} 19^{\prime} 27.6^{\prime \prime}$; Rubi-Télé $02^{\circ} 19^{\prime} 072^{\prime \prime}$ \& $024^{\circ} 58^{\prime} 36.8^{\prime \prime}$ and so UMA $00^{\circ} 33^{\prime} 15.2^{\prime \prime}$ \& $025^{\circ} 55^{\prime} 46.2^{\prime \prime}$. They are under the Equatorial climate of continental type (hot and humid).

\section{Material}

The biological material of this study was trees which were used for different measures.

\section{Data collection}

This study was conducted in the former Province Orientale and plots of $50 \mathrm{~m} \times 50 \mathrm{~m}$ at each site was installed. All species having circumferences with a diameter at the height of $1.30 \mathrm{~m}(\mathrm{dbh}) \geq 10 \mathrm{~cm}$ were inventoried. In addition, the botanical flora and works of Tropical Africa along with updated taxonomic catalogs were used for species identification. Some control samples were kept in the collection room of the Biodiversity Surveillance Centre of the University of Kisangani.

\section{Data treatment}

The treatment of data which was focused on the floristic similarity between the three sites was assessed 
using Morisita-Horn's similarity indices. This index corresponds to the ratio of the probability that two individuals randomly selected from two samples belong to the same species. The BiodivR program automatically calculates the values of this index according to $\mathrm{k}$. It varies from 0 to 1 , two plant communities are different if $\mathrm{MH}$ tends towards 0 (either all values $<0.5$ ) and identical if $\mathrm{MH}$ tends towards 1 (or all values $\geq 0.5$; value close to 1$)$.

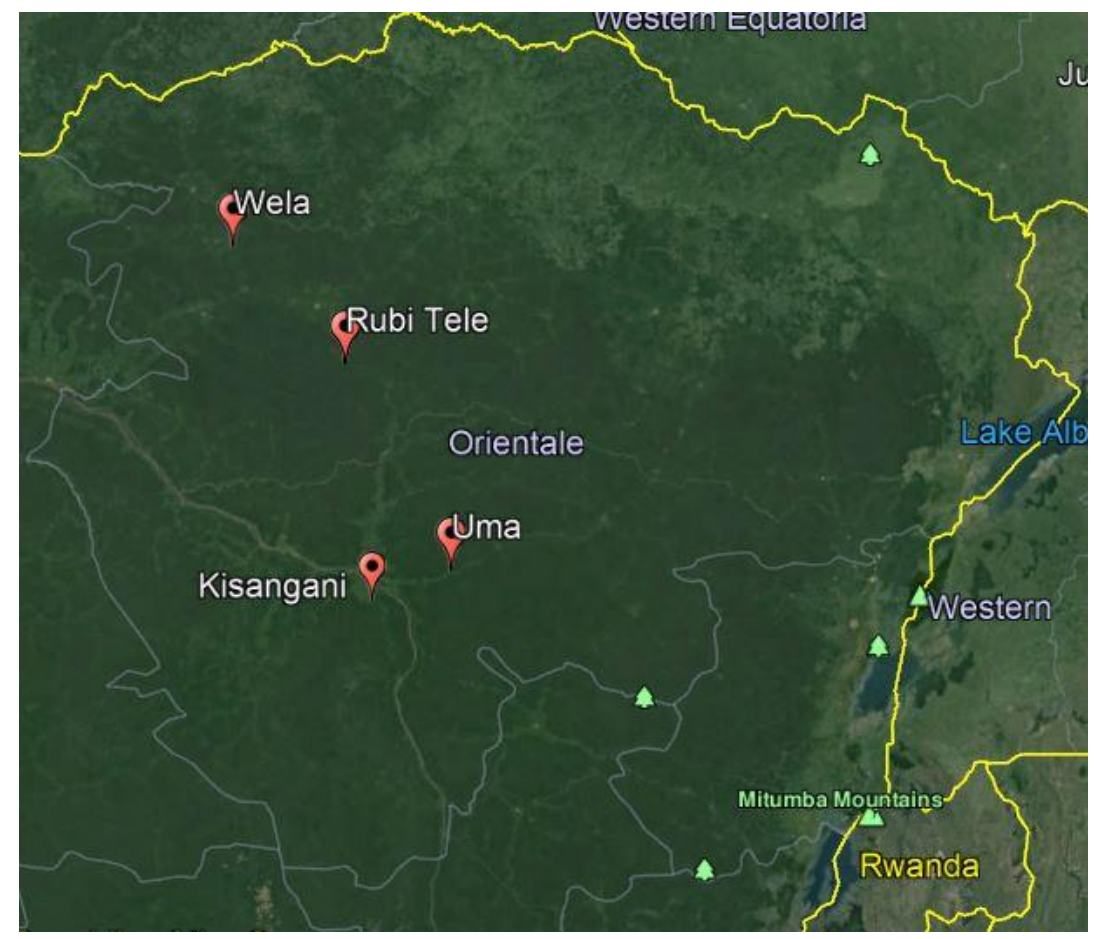

Figure 1. Map of the study area.

\section{Areal richness}

This analysis indicates the number of species collected per area unit and it is one of the most common measures of biodiversity.

\section{Indices of taxa importance values (IVI)}

It is the sum of the relative density, relative dominance for a taxon (Nshimba 2008).

$$
\mathrm{IVI}=\mathrm{AD}+\mathrm{RDom}+\mathrm{RF}
$$

Where: IVI is the index of importance values of taxa; AD: Absolute Density of taxa; RDom: Relative Dominance of Taxa, RF: Relative frequency.

\section{Relative frequency}

According to Curtis \& McIntosh (1950), the frequency of a species is equal to the number of occurrences of this species in the inventory area. The relative frequency of a species is equal to the quotient of frequency by the sum of frequencies of all species and multiplied by 100 (Nshimba 2008).

$$
\text { Relative Frequency of a species }=\frac{\text { Frequency of a species }}{\sum \text { Frequency of all species }} \times 100
$$

The area-species curve

It expresses the increase in the species number of species ( $\mathrm{Y}$ axis) according to the increasing surface (X axis). The area-species curve helps to determine the minimum area to be inventoried.

Diversity indices

Diversity indices used in this study were the following:

Shannon diversity Index (H'): indicates the species richness in a local ecosystem (Marcon 2015).

$$
H^{\prime}=\sum\left[\left(\frac{N i}{N}\right) * \log 2\left(\frac{N i}{N}\right)\right]
$$

Where, Ni: the total number of individuals of a given species (i ranging from 1 to $\sum$ ),

$\sum$ : the total number of species and

$\mathrm{N}$ : the total number of individuals.

It has to be noted that when $\mathrm{H}^{\prime}=0$ i.e. all individuals in a population belong to the same species. 
Piélou's equitability (EQ):

It is the ratio of the diversity of a population or sample and the number $\mathrm{N}$ of species present. It expresses the regularity, the equitable distribution of individuals within the plots.

$$
E Q=\frac{I S H}{\log 2(N)}
$$

Simpson diversity index

Simpson diversity index (D) allowed from the abundance data to analyze local biological diversity of different vegetal communities studied.

This index measures the probability that two randomly selected individuals belong to the same species:

$$
S=\sum f_{i} \text { et } f_{i}=N_{n i}
$$

Where, Ni: the number of individuals of a given species,

$\mathrm{N}$ : the total number of individuals.

This index will have a value of 0 to indicate the maximum diversity, and a value of 1 indicates the minimum diversity. In order to obtain "more intuitive" values, the Simpson diversity index represented by 1-D may be preferred, the maximum diversity maximum being represented by the value 1 , and the minimum diversity by the value 0 . It should be noted that this diversity index gives more weight to abundant species than to rare species. Adding rare species to a sample hardly changes the value of the diversity index.

Data analysis

Following floristic parameters analyzed were: abundance of species and family, indices of diversity and rarespecies curve. For the structural parameters, the terrial area variability and diametric structure were used. ANOVA test was used for the data that we had. These parameters were calculated using PAST version 2.17 and $\mathrm{R}$ version 3.4.0 softwares respectively.

\section{RESULTS AND DISCUSSION}

Floristic composition

A total of 1120 individuals distributed in 191 species and 40 families in these different sites was inventoried. The average basal area of these sites was of $25.40 \mathrm{~m}^{2} \mathrm{ha}^{-1}$. In Wela, 346 individuals gathered into 72 species and distributed in 30 families were inventoried while in Rubi-Télé, a total of 451 individuals grouped into 79 species and 29 families were listed and in UMA a total of 323 individuals was grouped into 59 species distributed into 24 families.

Significance value indices of species (IVI)

The significance index value of species of different sites are presented in the figures below.

1. Significance value index of Wela specie

For Wela species, the significance value index is presented in figure 2 below.

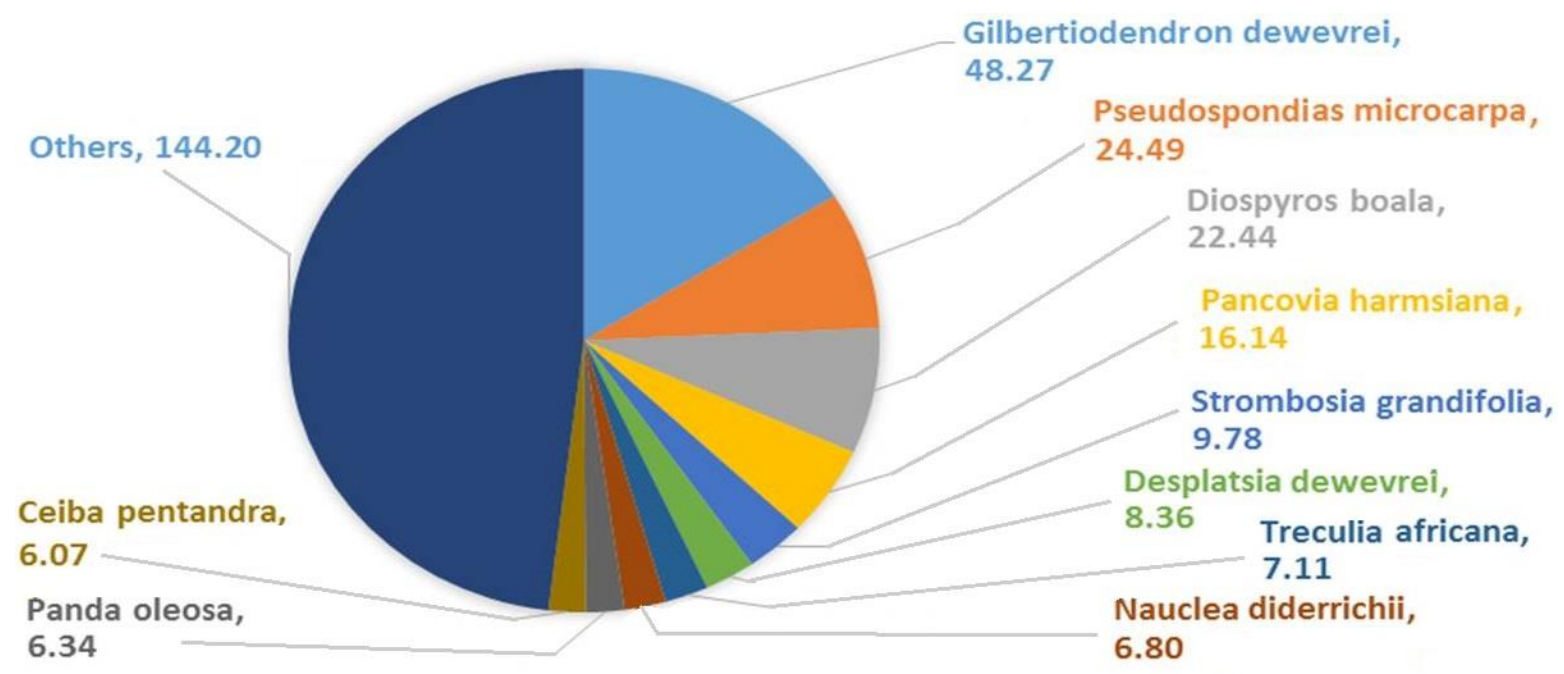

Figure 2. Significance value index of Wela species.

From the figure above, it can be observed that following species characterize Wela flora namely: Gilbertiodendron dewevrei (De Wild.) J.Léonard, Pseudospondias microcarpa (A. Rich.) Engl., Diospyros 
boala L., Pancovia harmisiana Gilg., Strombosia grandiflora Hook. f. ex Benth, Desplatsia dewevrei (De Wild. $\&$ Th. Dur.) Burret, Treculia africana Decne, Nauclea diderrichii Merr., Panda oleosa P. and Ceiba pentandra (L.) Gaertn.

2. Significance value index of Rubi-Télé species

The significance value index of Rubi-Télé species is presented in figure 3 .

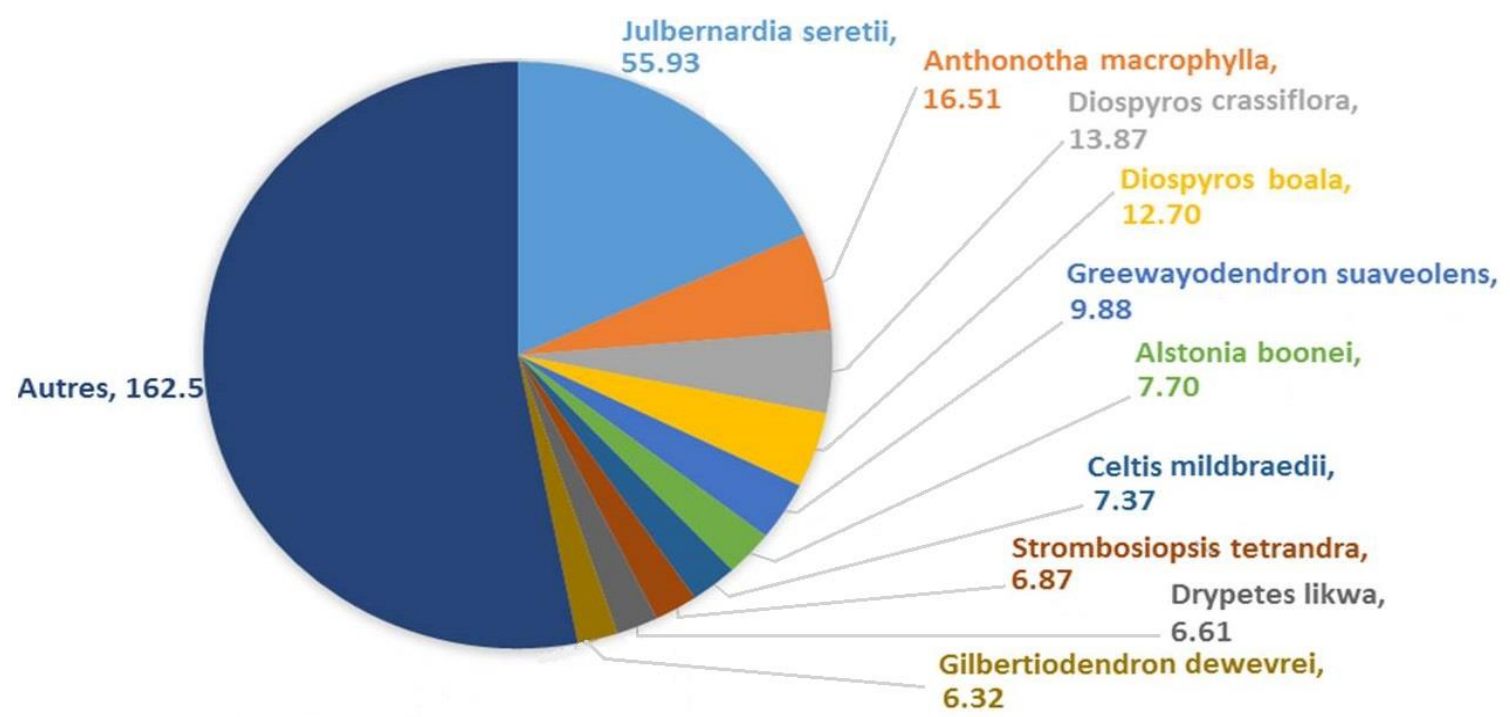

Figure 3. Significance value index of Rubi-Télé.

From the figure above, it can be observed that following species characterizing the Rubi-Télé flora are notably: Julbernardia seretii (De Wild.) T., Anthonotha macrophylla P. Beauv., Diospyros crassiflora Hiern., Diospyros boala De Wild., Greenwayodendron suaveolens Engl., Alstonia boonei De Wild., Celtis milbraedii Engl., Strombosiopsis tetrandra Engl., Drypetes likwa (Wight \& Arn.) Pax \& K.Hoffm. and Gilbertiodendron dewevrei (De Wild.) J.Léonard.

3. Significance value index of UMA species

The significance value index of UMA species is presented in figure 4.

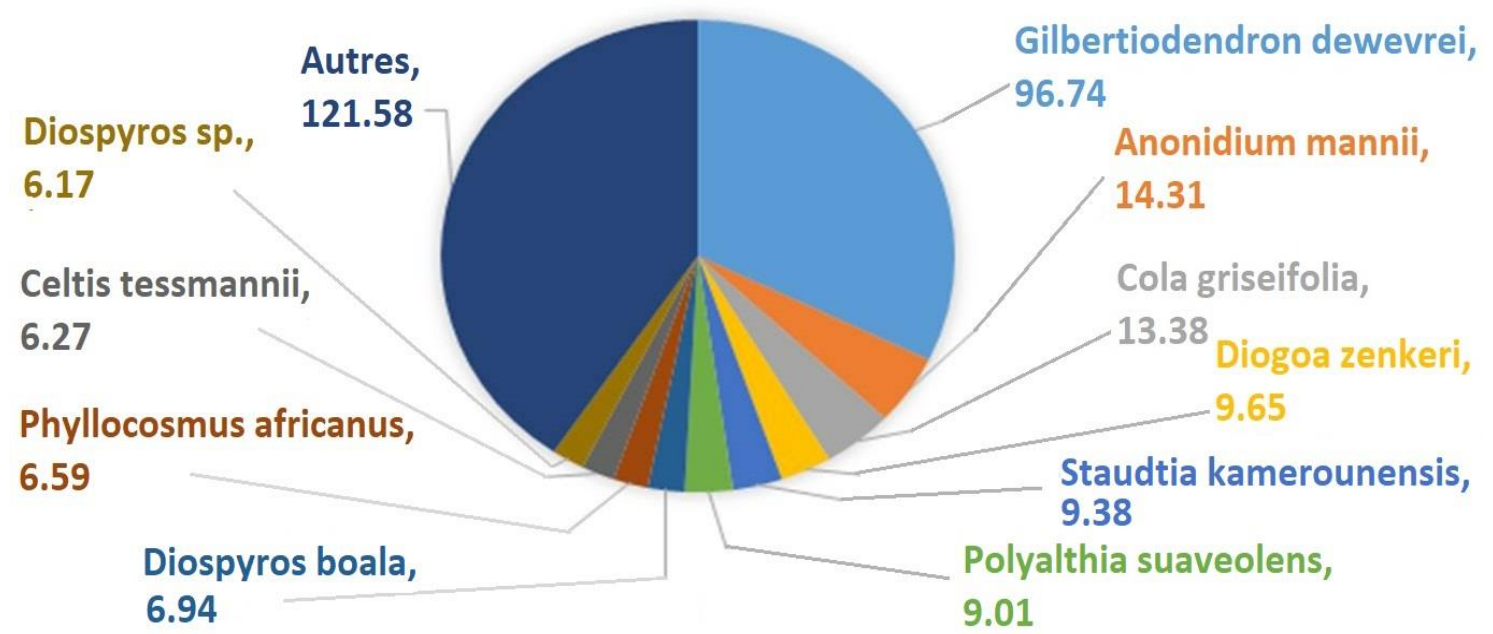

Figure 4. Significance value index of UMA.

From the figure above, it can be observed that following species characterize UMA flora are namely: Gilbertiodendron dewevrei (De Wild.) J.Léonard, Anonidium mannii (Oliv.) Engl. \& Diels, Cola griseifolia De Wild., Diogoa zenkeri Engl., Staudtia kamerounensis Warb., Polyalthia suaveolens Engl. \& Diels, Diospyros boala (H. Perrier) G.E. Schatz \& Lowry, Phyllocosmus africanus Hook.f, Celtis tessmanii Rendle and Diospyros sp.

Significance value indices of species for the three sites

1. Index of Morisita

The index of Morisita of different communities of the study sites is presented in figure 5. 


\section{Area-species curve}

The area-species curve expresses the increase in the number of species according to the increasing surface. It is often established to show the increase in the number of species with increasing surface area sampled. The figure 6 shows the area-species curve for selected three forests.

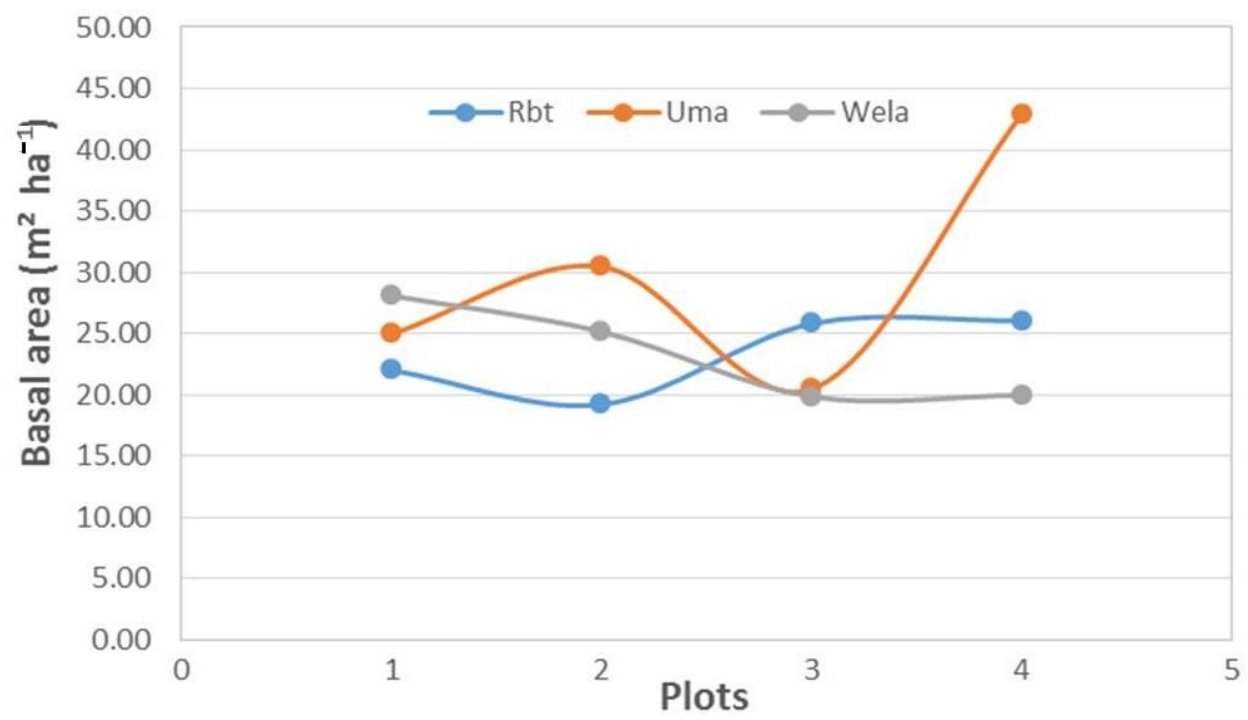

Figure 5. Index of Morisita. [Rbt- Rubi Télé]

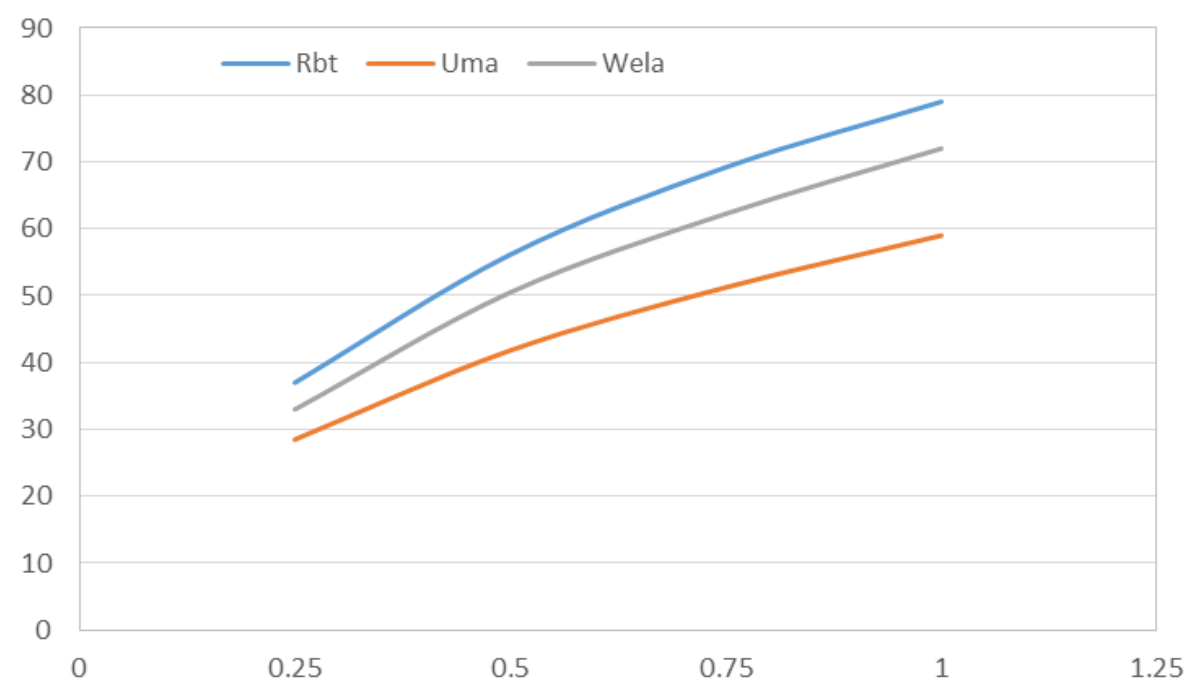

Figure 6. Area-species curve. [Rbt- Rubi Télé]

From the figure, it is clearly shown that the three sites are diversified though Rubi Télé is more diversified than the two other. Considering the trend of the curve, it is shown that the number of species increase with the sampled area for each site i.e. there is a probability to have new species for all the sites if an inventory was performed in a large area even when the number of plots is enlarged.

\section{Similarity between communities}

The similarity between communities is given in the table 1 .

Table 1. Similarity between communities.

\begin{tabular}{lrrr}
\hline & Rubi-Tele & UMA & Wela \\
\hline Rsubi-Tele & 79 & & \\
UMA & 0.154336 & 59 & \\
Wela & 0.005349 & 0.000457 & 72 \\
\hline
\end{tabular}

From this table, it is shown that Rubi-Télé is similar to UMA and Wela. This is due to the to environmental conditions, soil as well as the topography of UMA

\section{Diametric structure}

The density of the three sites is presented in the figure 7. The plots of Rubi Télé have a high density versus to UMA. It is important to note that environmental factors play a predominant role in this aspect. The two sites 
Rubi-Télé and UMA were located on land whereas Wela was located on the hydromorphic ground along the river called Itimbiri which stands out in diversity compared to other sites.

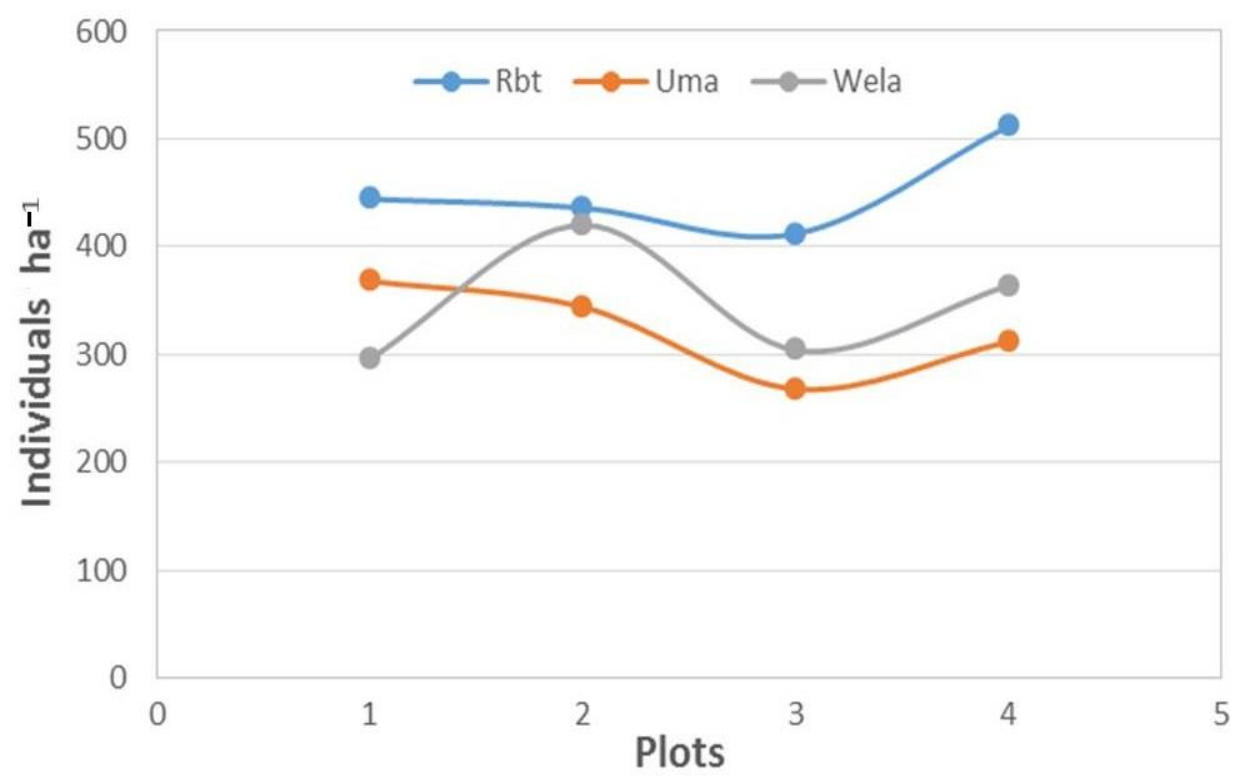

Figure 7. The density of the three sites.

\section{Distribution of species in diametric classes}

The distribution of species following the diametric classes is presented in the figure 8 .

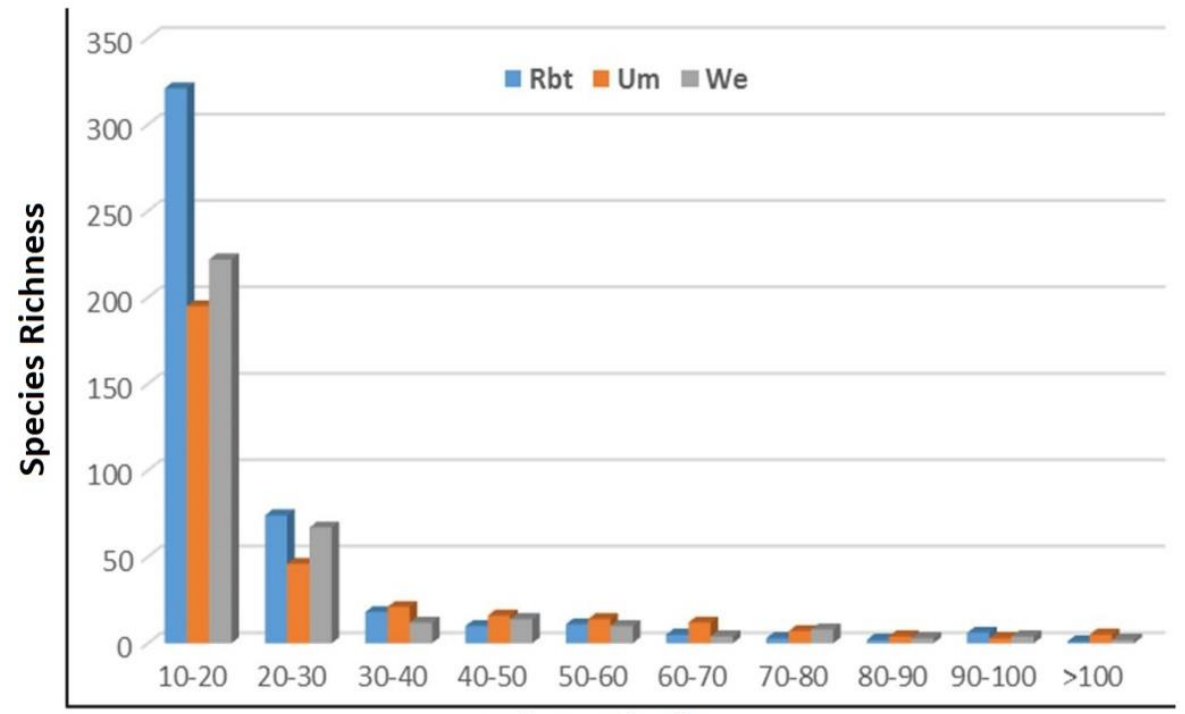

Diametric Classes

Figure 8. Distribution of species following the diametric classes. [Rbt- Rubi Télé]

From the figure, it can be observed that among the 10 diametric classes, the one ranging between 10 and 19 $\mathrm{cm}$ has a high number of individuals while other sites have fewer individuals. There was no statistical significance concerning the diversity of communities because the $F$ value is higher than the $p$ value. Regarding the density of extrapolation (per ha), there was a significance difference because the p value was less than 0.5 .

\section{Factorial Correspondence Analysis}

1. The classification

The factorial correspondence Analysis for different species is given in the figure 9. It emerges from this figure that the three communities are not different and have common species for each group, it has to be observed that the grouping of Wela has no common species with a long distance between the two other groups, But also the group of Wela was along the Itimbiri river while UMA was on a firm ground where the water does not influence the distribution of species. The identified plant communities share many species in common. From a deterministic point of view, this situation may be associated with low environmental heterogeneity. This hypothesis is however not validated in most tropical forests (Kouob 2009). 
The dendrogram displaying the hierarchical classification of the three vegetal communities is shown in figure 10 .

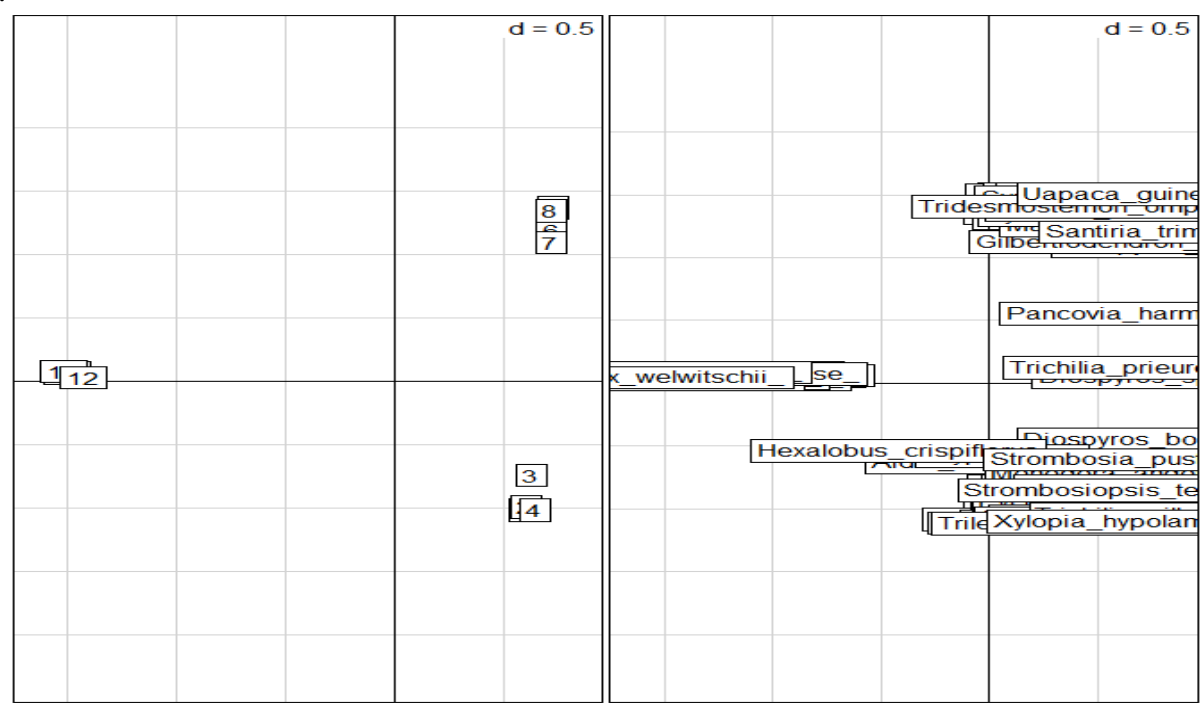

Figure 9. Factorial Correspondence Analysis.

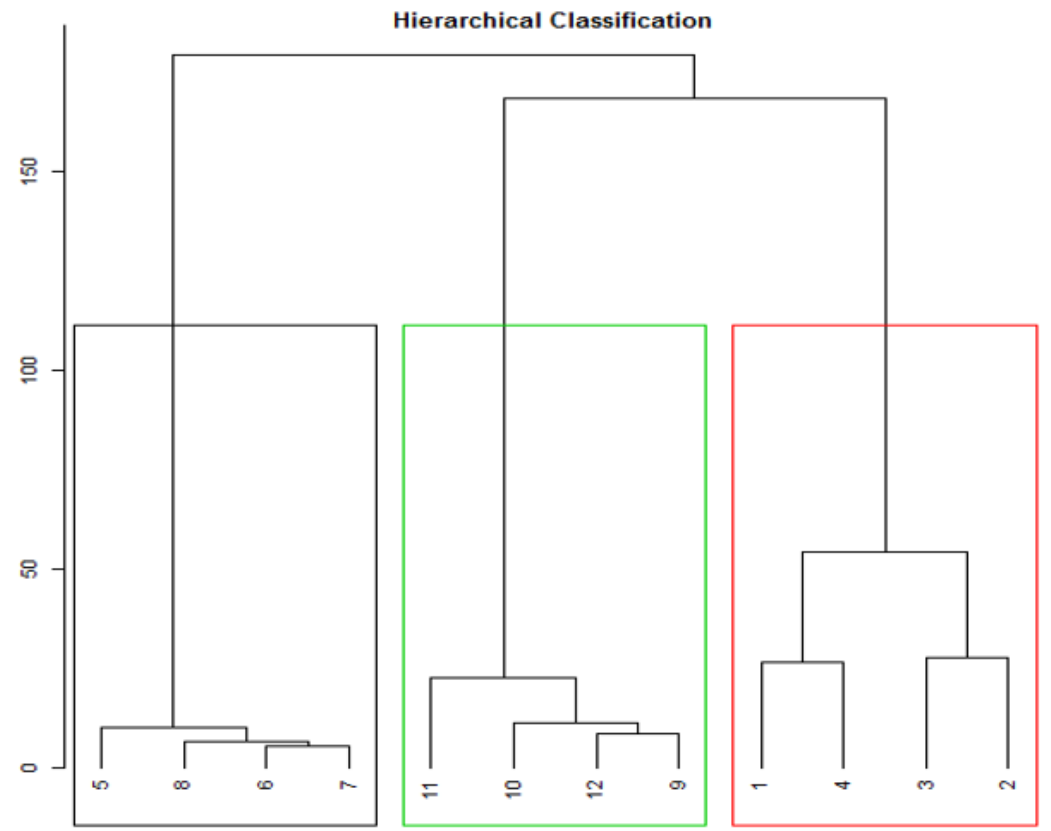

Figure 10. Dendrogram of three vegetal groups.

The classification of the surveys on the basis of the similarity index makes it possible to observe from $20 \%$ of similarity, three groups have been split. This classification reveals Wela's restriction to Rubi Télé and UMA. Initially the idea was to observe Rubi Télé and Wela grouped together because they are two sites located in the same axis but the above figure shows the contrary for Rubi Télé becomes a neighbor of UMA, it is up to us to report that these groups had a trend of a mono dominance, it is not really real mixed forests unlike Wela which shows its heterogeneity very advanced and away from these two groups.

\section{DISCUSSION}

Plant diversity and ecosystem functioning

In Tropical rainforests, the great diversity of plants generally requires that inventories can be limited according to the problem and the type of vegetation. In this study, the analyses focused on the floristic and structural diversity of three groups. To achieve this goal, data were collected in plots of $50 \mathrm{~m} \times 50 \mathrm{~m}$. Therefore, the results of this study may be different from those obtained in other surveys of different sizes and shapes. The number of individuals identified for the specificity or attributed to a morphospecies depends on the experience of the botanist who conducted the inventory, the time spent on taxonomic analyzes and the collection of herbarium samples (Parmentier et al. 2007). 
The richness of temperate forests ranges between 15 and 25 species, that of dry tropical forests between 50 and 60 , it reaches about 150 species in tropical rainforests and 250 species in equatorial forests where the dry season is non-existent (Gentry 1992) and the current results are in the same range because 191 species were identified in the different plots used in this study. The diversity of the elements of a community is a key concept which is vital for the analysis.

The concept of diversity has two aspects namely: the number of element categories, the number of distinct taxa, then we talk about specific diversity for species and generic diversity for genera, and on the other hand, the regularity, which is the way in which individuals are divided among different taxa categories (Marion et al. 2003). Of the total of 90 families surveyed, 80 families were recognized in the dry land forest, 67 in the periodically flooded forest and 64 other families in the swamp forest. The Euphorbiaceae, Rubiaceae, and Caesalpiniaceae families had higher specific and generic diversity compared to others. Sonke (1998) reported that the compiled floristic data from three surveys showed the dominance of Rubiaceae (37\%) and Fabaceae (16.7\%), followed by Apocynaceae and Euphorbiaceae with $11.1 \%$ each. As for the weighted spectrum of the flora, a preponderance of Ochnaceae $(28.9 \%)$ and Rubiaceae $(26.3 \%)$ was noted. They were followed by Bignoniaceae (10.5\%), Euphorbiaceae (6.9\%) and Achariaceae (6\%). For the current work, two plots were settled consecutively on the mainland and the other one was along the Itimbiri river. The finding of the current study is different from this author quoted above.

Kouob (2009) reported that the classification of the surveys on the basis of the Sorensen similarity index makes it possible to observe from $40 \%$ of similarity, 2 groups of 34 and 32 surveys, as well as 4 marginal surveys. From $45 \%$ of similarity, the 34 western records of the RBD (FO) form 3 subgroups, while the 32 eastern records of the RBD (FE) form 2 subgroups. This classification revealed the restriction of Distemonanthus benthamianus Baill., Dacryodes buettneri (Engl.) H.J.Lam and Dichostemma glaucescens Pierre in the western groups (FO) of the RBD, and Scorodophleus zenkeri Harms, Afrostyrax lepidophyllus Mildbr., Pausinystalia macroceras (K.Schum.) Pierre in the eastern groups of the RBD (FE).

Kambale (2016b,c), Nshimba (2008) and Sonke (1998) reported that its Sorrensen similarity coefficients ranged between 0 and 1 in his research on three different sites located at the Mbiye Island. The UPGMA method (Unweighted pair group median average) gives equal weight to each point in each forest. By presenting his results in a dendrogram, the above authors found that the presence of certain species is limited in certain types of forests. The floristic distances are small in these three sites, but these results show a good classification in the ordination of heterogeneity in the contact zone. In the present work, the classification of the statements on the basis of the index of similarity allows the observation of $20 \%$ of similarity of the three groups studied. This classification reveals Wela's restriction to Rubi Télé and UMA.

\section{CONCLUSION}

The floristic characterization of three groups of which two on land and one on the hydromorphic ground (along the Itimbiri river) shows a richness as well as a similarity between them. It is worth pointing out that UMA is more similar to Rubi téle than Wela and it is hoped that it is due to environmental factors but also to the edaphic factors.

It was found that the two plant formation has in common the most species. A significant part of this diversity to Rubi-Télé reveals such a strong heterogeneity of species which demonstrates the presence of a good nonenthropized mature forest than Wela. To this end, the solutions currently envisaged for the conservation of tropical rainforests, in particular, the establishment of biological reserves, sustainable forestry, the restoration of degraded forests or the creation of forest plantations, require a deepening of knowledge of the ecology and dynamics of regeneration of tree species in ecosystems.

\section{ACKNOWLEDGMENTS}

We express our gratefulness to the Centre de Surveillance de la Biodiversité (CSB, Kisangani) for its support to the realization of this study.

\section{REFERENCES}

Asimonyio JA, Kambale K, Shutsha RE, Bongo GN, Tshibangu DST, Mpiana PT \& Ngbolua KN (2015b) Phytoecological Study of UMA Forest (Kisangani City, Democratic Republic Of The Congo). Journal of Advanced Botany and Zoology 3(2): 1-4. [DOI: 10.15297/JABZ.V3I2.01]

Asimonyio JA, Ngabu JC, Lomba CB, Falanga CM, Mpiana PT \& Ngbolua KN (2015a) Structure et diversité d'un peuplement forestier hétérogène dans le bloc sud de la réserve forestière de Yoko (Ubundu, République 
Démocratique du Congo). International Journal of Innovation and Scientific Research 18(2): 241-251.

Bajpai O, Kushwaha AK, Srivastava AK, Pandey J \& Chaudhary LB (2015) Phytosociological status of a monotypic genus Indopiptadenia: A Near Threatened Tree from the Terai-Bhabar Region of Central Himalaya. Research Journal of Forestry 9(2): 35-47.

Bajpai O, Suman S \& Upadhyay N (2017) Ecological exploration of Kuwana forest A tropical moist deciduous forest of eastern Terai, India. Annals of Plant Sciences 6(12): 1811-1816.

Blanc L, Flores O, Molino JF, Gourlet-Fleury S \& Sebatier D (2003) La diversité spécifique et regroupement d'espèces arborescentes en forêt guyanaise. In: Revue forestière française (Nancy). Numéro spécial. Connaissance et gestion de la forêt guyanaise, no. 21, pp. 131-146.

Carpentier GC (1999) Analyse de la biodiversité à partir d'une liste d'occurrences d'espèces, nouvelles méthodes d'ordination appliquées à l'étude de l'endémisme dans les Ghats occidentaux, (Thèse de doctorat). Université Claude Bernard-Lyon I, 234 p.

CBD - Convention on Biological Diversity (2012) Protocole de Nagoya sur l'accès aux ressources génétiques et le partage juste et équitable des avantages découlant de leur utilisation relatif à la convention sur la diversité biologique tous droits réservés. $16 \mathrm{p}$.

CSB - Centre de Surveillance de Biodiversité (2014) Centre de Surveillance de la Biodiversité : Etat des lieux de la biodiversité dans la RD Congo. In: $1^{\text {st }}$ International Conference on Biodiversity in the Congo Basin, 610 June 2014, Kisangani, DRC.

Curtis JT \& Mclntosh RP (1950) The Interrelations of certain analytic and synthetic phytosociological characters. Ecology 31(3): 434-455.

Gentry AH (1992) Diversity and floristic composition of Andean forests of Peru and adjacent countries: implications for their conservation. Memorias del Museo de Historia Natural 21: 11-29.

Kambale KB, Shalufa AN, Ntahobavuka HH \& Mangambu MJD (2016a) Floristic characterization of the ecotonal zone between the Gilbertiodendron dewevrei (De Wild) J. Leonard (Fabaceae) Forest and the semideciduous mixed forest in Mbiye island (Congo Basin, DR Congo). Journal of Biodiversity and Environmental Sciences 9(4): 20-33.

Kambale KJL, Asimonyio JA, Shutsha ER, Katembo EW, Tsongo JM, Yokana EI, Bukasa KK, Nshimba HS, Mpiana PT, Kavira PK \& Ngbolua KN (2016b) Etudes floristique et structurale des forêts dans le domaine de chasse de Rubi-Télé (Province de Bas-Uélé, République Démocratique du Congo). International Journal of Innovation and Scientific Research 24(2): 309-321.

Kambale KJL, Shutsha RE, Katembo EW, Omatoko JM, Kirongozi FB, Bugentho EP, Yokana EI, Bukasa KK, Nshimba HS, Basa OD \& Koto-te-Nyiwa Ngbolua KN (2016c) Etude floristique et structurale de deux groupements végétaux mixtes sur terre hydromorphe et ferme de la forêt de Kponyo (Province du Bas-Uélé, R.D. Congo). International Journal of Innovation and Scientific Research 24(2): 300-308.

Kouob BS (2009) Organisation de la diversité végétale dans les forêts matures de terre ferme du sud-est Cameroun, (Thèse de doctorat). Université Libre de Bruxelles, 212 p.

Marcon E (2015) Mesures de la biodiversité. UMR Ecologie des Forêts de Guyane, France, p. 202.

Marion G., Frédéric G., Berges L \& Dumas Y (2003) Biodiversité et Gestion Forestière : connaitre pour préserver. Journées Francophones de Conservation de la Biodiversité - UCBL Villeurbanne, 22-25 avril 2003.

Marquant B, Mosnier A, Bodin B, Dessard H, Feintrenie L, Molto Q, Gond V \& Bayol N (2015) Numéro spéciale de l'état des forêts. Belgique, pp. 128.

Masens da-Musa YB, Ngbolua K-t-N, Masens M, Tambu TM \& Gédéon NB (2017) Phytoecological study of Nzundu massif forest of Imbongo city, Kwilu Province, Democratic Republic of the Congo. Tropical Plant Research 4(3): 363-375.

Nshimba SM (2008) Etude floristique, écologique et phytosociologique des forêts de l'île Mbiye à Kisangani, RDC, (Thèse de doctorat). Faculté des Sciences, Université Libre de Bruxelles, 272 p.

Omatoko J, Nshimba H, Bogaert J, Lejoly J, Shutsha R, Shaumba JP, Asimonyio J \& Ngbolua KN (2015) Etudes floristique et structurale des peuplements sur sols argileux à Pericopsis elata et sableux à Julbernardia seretii dans la forêt de plaine de UMA en République Démocratique du Congo. International Journal of Innovation and Applied Studies 13(2): 452-463.

Parmentier I, Malhi Y, Senterre B, Whittaker RJ, Alonso A, Balinga MPB, Bakayoko A, Bongers F, Chatelain C, Comiskey JA, Cortay R, Kamdem MND, Doucet JL, Gautier L, Hawthorne WD, Issembe YA, Kouamé FN, Kouka LA, Leal ME, Lejoly J, Lewis SL, Nusbaumer L, Parren MPE, Peh KSH, Phillips OL, Sheil D, 
Sonké B, Sosef MSM, Sunderland TCH, Stropp J, Steege HT, Swaine MD, Tchouto MGP, Van Gemerden BS, Van Valkenburg JLCH \& Wöll H (2007) The Odd Man Out? Might Climate Explain the Lower Tree Alpha-Diversity of African Rain Forests Relative to Amazonian Rain Forests? Journal of Ecology 95: 10581071.

Sambare O, Bognounou F, Wittig R \& Thiombiano A (2011) Woody species composition, diversity and structure of riparian forests of four watercourses types in Burkina Faso. Journal of Forestry Research 22: $145-158$.

Sonke B (1998) Etudes floristiques et structurales des forêts de la réserve de Faune du Dja, (Thèse de doctorat). Université Libre de Bruxelles, Belgique.

Timilsina N, Ross MS \& Heinen JT (2007) A community analysis of sal (Shorea robusta) forests in the western Terai of Nepal. Forest Ecology and Management 241: 223-234.

Trichon V (1997) Hétérogénéité spatiale d'une forêt tropicale humide de Sumatra : Effet de la Topographie sur la structure floristique. Laboratoire d'écologie terrestre, UMR 5552 (CNRS / UPS) Toulouse cedex, France. Annales Sciences Forestières 54(5): 431-446. 